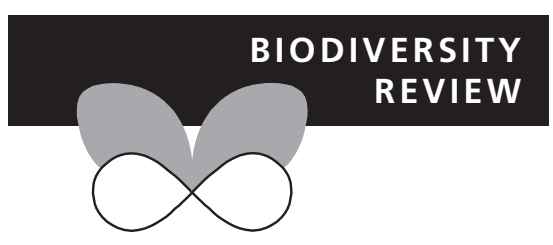

\title{
Ecophysiological traits associated with the competitive ability of invasive Australian acacias
}

Taryn L. Morris ${ }^{1,2 \star}$, Karen J. Esler ${ }^{3,4}$, Nichole N. Barger ${ }^{1}$, Shayne M. Jacobs ${ }^{3}$ and Michael D. Cramer ${ }^{2,5}$

${ }^{1}$ Department of Ecology and Evolutionary Biology, Campus Box 334, University of Colorado, Boulder, CO 80309, USA, ${ }^{2}$ Department of Botany, University of Cape Town, Private Bag X3, Rondebosch, 7701, South Africa, ${ }^{3}$ Department of Conservation Ecology and Entomology, Stellenbosch University, Private Bag X1, Matieland 7602, Stellenbosch, South Africa, ${ }^{4}$ Centre for Invasion Biology, Stellenbosch University, Private Bag X1, Matieland 7602, Stellenbosch, South Africa, ${ }^{5}$ School of Plant Biology, Faculty of Natural and Agricultural Sciences, The University of Western Australia, 35 Stirling Highway, Crawley, WA 6009, Australia

${ }^{*}$ Correspondence: Taryn Morris, Department of Ecology and Evolutionary Biology, Campus Box 334, University of Colorado, Boulder, CO 80309, USA.

E-mail: taryn.morris@colorado.edu

\section{ABSTRACT}

Aim We explored morphological and ecophysiological traits that enable invasive Australian acacias to compete with native species for resources (light, water and nutrients) necessary to support the substantial growth associated with successful invasions.

\section{Location Global.}

Results Invasive Australian acacias grow large and seed prolifically in invaded regions. The greater capacity for vegetative growth is underpinned by their ability to acquire and efficiently use resources in non-native habitats. Key biological traits that enhance acquisition include (1) rapid and substantial allocation to root mass (up to 6-fold more than co-occurring native species) directed towards deep roots (at least 50\% longer than those of natives) and to extensive shallow root networks; (2) heteroblasty, in most species, conferring high relative growth rates as bipinnate seedlings but long-lived, nutrient-conserving phyllodes as adults and (3) strong $\mathrm{N}_{2}$-fixation abilities.

Main conclusions The ecophysiological traits that govern the competitive interaction of invasive Australian acacias with native species are an important component of the recognized suite of factors including introduction history, human use and enemy release that combine to produce successful invasions. Traits interact to give Australian acacias competitive advantage over many native species. One such interaction is that of $\mathrm{N}_{2}$ fixation, which when coupled with slow decomposition of sclerophyllous phyllodes results in alteration of soil nutrient cycling. The lasting legacy of soil $\mathrm{N}$-enrichment hinders the competitive ability of native species and further enhances invasions. The importance of edaphic factors and competitive interactions in determining invasive success should be considered in predictive modelling of species distributions.

\section{Keywords}

Biological invasions, Cape Floristic Region, fynbos, phyllodes, relative growth rate, water-use efficiency.

\section{INTRODUCTION}

The ability of alien species to establish, grow and survive in non-native environments is highly dependent on their ability to compete with native species for the essential resources of light, water and nutrients. Australian acacias (1012 species in the subgenus Phyllodineae DC native to Australia; Miller et al., 2011; Richardson et al., 2011) are some of the most successful and prolific invasive species globally (Lowe et al., 2000; Henderson, 2007; Richardson \& Rejmánek, 2011). Invasive
Australian acacias successfully compete for resources in nonnative environments (Werner et al., 2008), enabling them to realize their potential to grow larger than native vegetation (Table 1). Success of invaders is irrefutably also contingent on several other factors (Rejmánek et al., 2005; Thuiller et al., 2006). For example, the history of introduction (both frequency and magnitude) and the human use of the introduced species play an important role in the subsequent scale of invasion (Lockwood et al., 2005; Wilson et al., 2007; Carruthers et al., 2011; Castro-Díez et al., 2011; Griffin et al., 2011; 
Resource acquisition and use by invasive Australian acacias

Table 1 Height, above-ground biomass and normalized difference vegetation index (NDVI) of invasive Australian acacia stands in comparison with native vegetation in the Cape Floristic Region (CFR), South Africa. Values indicate means \pm SE, where available.

\begin{tabular}{|c|c|c|c|c|}
\hline Acacia spp. & Measure & Acacia & Native & Reference \\
\hline A. saligna & Height (m) & 6.0 & 2.5 & $\begin{array}{l}\text { van Wilgen \& } \\
\text { Richardson, } 1985\end{array}$ \\
\hline A. cyclops \& A. saligna & Biomass $\left(\mathrm{kg} \mathrm{m}^{-2}\right)$ & 10.4 & $2.0-3.5$ & Milton \& Siegfried, 1981 \\
\hline A. saligna & Biomass $\left(\mathrm{kg} \mathrm{m}^{-2}\right)$ & 5.8 & 1.8 & $\begin{array}{l}\text { van Wilgen \& } \\
\text { Richardson, } 1985\end{array}$ \\
\hline A. cyclops \& A. saligna & NDVI & $0.63 \pm 0.01$ & $0.51 \pm 0.01$ & Fatoki, 2007 \\
\hline
\end{tabular}

Kull et al., 2011; van Wilgen et al., 2011). Reproductive and dispersal strategies can also influence the likelihood of invasion success (Gibson et al., 2011). Furthermore, the absence of pests and pathogens of alien species in their new range also enhances the competitiveness of alien species (Williamson, 1996; Crawley, 1997). In this article, however, we focus on identifying ecophysiological traits and mechanisms enabling acquisition and conservation of resources that contribute to competitive success of Australian acacias in non-native ranges.

Of the c. 300 Australian Acacia spp. introduced around the world, 23 have become highly invasive (Richardson \& Rejmánek, 2011), particularly in Mediterranean-type ecosystems that are often water- and/or nutrient limited such as the South African Cape Floristic Region (CFR) or Portuguese dune ecosystems (Groves \& di Castri, 1991; Witkowski, 1991a; Stock et al., 1995; Marchante et al., 2003; Rouget et al., 2003; Werner et al., 2010) and disturbed environments such as riparian and post-fire environments (Henderson, 2007; Richardson et al., 2007). The effects of Australian acacia invasions on native ecosystems have been widely documented with a range of recorded impacts (reviewed in van Wilgen et al., 2008; Le Maitre et al., 2011) including declines in native species diversities (Richardson et al., 1989; Holmes \& Cowling, 1997; Marchante et al., 2003), reductions in stream flows because of increased water use (Enright, 2000; Dye et al., 2001), alterations to nutrient cycling (Yelenik et al., 2004) and modifications to fire regimes (van Wilgen \& Richardson, 1985). Many of these impacts are linked with the propensity of the Australian acacias to grow much larger, in both height and total biomass, than the native vegetation in invaded ranges (e.g. Table 1). The vigorous vegetative growth of these plants also supports prolific production of nutrient-rich seeds, leading to large, persistent seed banks (Milton, 1980; Holmes, 1989; Gibson et al., 2011), which are a major factor contributing to their successful invasion and persistence (Richardson \& Kluge, 2008).

Competition for the resources to support this growth capacity depends on characteristics of both the invaded region and the invader's biological traits (Thuiller et al., 2006). Disturbance and the native plant community matrix in the invaded region strongly influence the distribution and availability of resources to alien plants. The 'Empty Niche Hypothesis' suggests that alien plants are able to establish, persist and invade in novel environments by accessing resources not utilized by native flora (Elton, 1958; MacArthur, 1970). This was expanded upon by Davis et al. (2000) in the 'Fluctuating Resource Hypothesis', which proposes that invasions are facilitated only when resources fluctuate (as a result of excess inputs into the system or reduced use by native flora) and temporarily become available for acquisition by invasive species.

Whether the invader can capitalize on the availability of resources is governed by its biological traits. Researchers have, over several decades, investigated which biological traits confer success of invaders over native species (Baker, 1974; Rejmánek \& Richardson, 1996; Pyšek \& Richardson, 2007). One key trait commonly recognized to support successful invasions is the ability of aliens to better acquire limiting resources or to use resources more efficiently than native species (e.g. Vitousek, 1986; Cordell et al., 2002; Funk \& Vitousek, 2007). Here, we review key ecophysiological traits and mechanisms that enable invasive Australian acacias to acquire the resources (light, water and nutrients) necessary to support the greater vegetative growth and meet the reproductive costs associated with successful invasions.

\section{RESOURCE ACQUISITION AND USE BY INVASIVE AUSTRALIAN ACACIAS}

\section{Light}

Competition for light is likely to be most fierce during germination. Invasive Australian acacia seedlings grow taller (Acacia mangium 50\% taller than a common heath-forest species in Borneo, Melastoma beccarianum, Osunkoya et al., 2005; A. saligna $123 \%$ taller than a fynbos biome species in South Africa, Protea repens, Witkowski, 1991b) and faster than native species (Witkowski, 1991b; Peperkorn et al., 2005; Osunkoya et al., 2005). Once established, the fast-growing Australian acacias overtop native vegetation, out-competing native species for light (Rutherford \& de Bösenberg, 1988). As a consequence, native vegetation most often cannot survive under the dense invasive Australian acacia canopies, leaving the understory bare (Holmes \& Cowling, 1997). If native vegetation is able to persist, it is often only at the acacia canopy edge or at low levels in the understory (Midgley et al., 1992). The high growth rates of Australian acacias are most likely supported by the superior abilities of Australian acacia seedlings to obtain necessary water and nutrients.

\section{Water}

Water depletion in invaded ecosystems is considered one of the most significant impacts of Australian acacia species (Le Maitre 


\section{T. L. Morris et al.}

et al., 1996, 2000; Enright, 2000; Le Maitre, 2004). Several studies provide evidence for increased water use by Australian acacias in invaded regions. In a Portuguese pine forest, stand water use increased by $6.5 \%$ because of Acacia longifolia invasions (Table 2). Evapotranspiration (ET) was 13-51\% higher in A. mearnsii stands compared with native vegetation in southern African grassland and CFR sites (Table 2). Furthermore, invasive Australian acacias decreased the water yield of sampled South African river catchments by up to $5 \%$ (Table 2), a value predicted to increase dramatically with the projected spread of invasions (Le Maitre et al., 2002). Increased water use is likely a result of larger above-ground biomasses (c. 3-fold greater) of Australian acacia stands compared with native vegetation (Table 1). Larger aboveground biomass yields an associated higher leaf area for transpiration as indicated using normalized difference vegetation index data (NDVI) as a proxy for leaf area index (Turner et al., 1999), which was $25 \%$ greater in invasive Australian acacia stands compared with native CFR vegetation (Table 1 ).

Apart from water loss because of greater above-ground biomass, leaf-specific water loss (i.e. transpiration rates) of invasive Australian acacias is also an important consideration, although relatively poorly documented. Rutherford \& de Bösenberg (1988) reported that A. cyclops generally had higher transpiration rates per leaf area than indigenous fynbos species. Further studies would thus be useful in determining whether increased water use is mostly owing to larger above-ground biomass or also partially because of increased transpiration rates per leaf area. What is of interest is how invasive Australian acacias access these significant volumes of water.

\section{Water acquisition}

Plant water acquisition is dependent on the size, surface area and depth of its roots as well as how these roots are spatially distributed through the soil profile (Shenk \& Jackson, 2002). Invasive Australian acacias generally have a higher investment in rootstocks (measured by root mass ratio; RMR) than native species, yielding a higher biomass of roots (Table 3 ) with a surface area 2- to 6-fold greater than that of native species (Werner et al., 2010). Australian acacia seedlings also develop roots 1.5 - to 4 -fold longer than co-occurring native species (Table 3), which penetrate deeper into the soil profile (Witkowski, 1991b). This occurs at significantly faster rates than that of native vegetation with no associated reduction in above-ground biomasses (Witkowski, 1991b; Musil, 1993; Peperkorn et al., 2005). The substantial and rapid root growth of acacia seedlings enables these plants to out-compete native species for water, especially during water-limited periods, a trait that has also been recognized as an advantage for other invasive species (Roché et al., 1994). Data on rooting patterns of larger, mature Australian acacias are sparse. However, considering the substantial initial root investment and strong correlations between above-ground and below-ground biomass of trees (e.g. Robinson, 2004), it is likely that large adult invasive Australian acacias also have substantially greater root investment than native species. One study described how A. saligna, when grown in a mixed stand with Eucalyptus and Atriplex, had roots as deep as $6 \mathrm{~m}$ within 4 years of planting and at one site had roots up to $16 \mathrm{~m}$ deep after several additional years (Knight et al., 2002). Further information about rooting depth is imperative for understanding the capacity of invasive Australian acacias to access deep water (and associated nutrient sources) possibly facilitating competitive exclusion of native species.

The spatial distribution of root biomass is also of great importance in determining the success of sustained water acquisition. A dimorphic root system comprising both deep roots enabling water acquisition during dry periods and a dense shallow network of surface roots that obtain water from the upper soil horizon in wetter periods is of great benefit (Pate et al., 1995; Canadell et al., 1996; Joffre et al., 2007). Juvenile A. saligna and A. cyclops show dimorphic roots in the invaded CFR, South Africa (Hoffman \& Mitchell, 1986), whereas the native Fabaceae species compared, Aspalathus albens, A. flexuosa and Rafnia angulata, have significantly fewer surface lateral roots, with no lateral roots at all in the dry summer (Hoffman \& Mitchell, 1986).

Overall, invasive Australian acacias show substantial initial below-ground investment producing bigger root systems that penetrate deeper into the soil in comparison with native species. Both the size and the spatial distribution of roots

\begin{tabular}{|c|c|c|c|c|c|}
\hline Acacia spp. & Country & $\begin{array}{l}\text { Vegetation } \\
\text { type }\end{array}$ & Measurement & Effect & Reference \\
\hline A. longifolia & Portugal & Pine forest & Stand water use & $6.5 \%$ increase & $\begin{array}{l}\text { Rascher et al., } \\
2009\end{array}$ \\
\hline A. mearnsii & South Africa & $\begin{array}{l}\text { CFR } \\
\text { vegetation }\end{array}$ & ET & $13 \%$ increase & $\begin{array}{l}\text { Dye et al., } \\
2001\end{array}$ \\
\hline A. mearnsii & South Africa & Grassland & ET & $51 \%$ increase & $\begin{array}{l}\text { Dye et al. } \\
2001\end{array}$ \\
\hline Acacia spp.* & South Africa & $\begin{array}{l}\text { Native } \\
\text { vegetation }\end{array}$ & $\begin{array}{l}\text { Water yield of } \\
\text { catchment }\end{array}$ & $1-5 \%$ reduction & $\begin{array}{l}\text { Le Maitre et al., } \\
2002\end{array}$ \\
\hline
\end{tabular}

${ }^{*}$ Mixed species including A. cyclops, A. dealbata, A. longifolia, A. mearnsii, A. melanoxylon and A. saligna.
Table 2 The effect of Australian acacia invasions on stand level water use (scaled up from individual tree sap flows derived using Granier's constant heat method), modelled evapotranspiration (ET) derived using the Bowen ratio energy balance technique, and estimated water yields of sampled catchment areas (based on biomass-based regression models) when compared to native uninvaded vegetation. 
Resource acquisition and use by invasive Australian acacias

Table 3 Comparison of root mass ratios (RMR), root biomass and root length indicated by a ratio of the measure comparing invasive Australian acacia seedlings to co-occurring native species in invaded ranges. Data are for vegetation varying from 6 to 18 months in age.

\begin{tabular}{|c|c|c|c|c|c|c|c|}
\hline Acacia spp. & Region & Native spp. & $\begin{array}{l}\text { Vegetation } \\
\text { age (months) }\end{array}$ & RMR & $\begin{array}{l}\text { Root } \\
\text { biomass }\end{array}$ & $\begin{array}{l}\text { Root } \\
\text { length }\end{array}$ & Reference \\
\hline \multirow[t]{2}{*}{ A. longifolia } & Portugal & $\begin{array}{l}\text { Halimium } \\
\text { halimifolium }\end{array}$ & 7 & $1.5 \times$ & $3.0 \times$ & $1.6 \times$ & $\begin{array}{l}\text { Peperkorn et al., } \\
2005\end{array}$ \\
\hline & & Pinus pinea & & $0.7 x$ & $0.9 x$ & $4.1 \times$ & \\
\hline A. saligna & CFR & Protea repens & 6 & $1.6 \times$ & $15.0 \times$ & $1.8 \times$ & Witkowski, 1991b \\
\hline \multirow[t]{3}{*}{ A. saligna } & CFR & Ericoid spp. & 18 & $1.6 \times$ & $3.3 \times$ & $1.7 \times$ & Musil, 1993 \\
\hline & & Restioid spp. & & $0.5 \times$ & $1.8 \times$ & $1.9 \times$ & \\
\hline & & Proteoid spp. & & $1.5 \times$ & $2.5 x$ & $1.5 \times$ & \\
\hline
\end{tabular}

provide an early competitive advantage for water acquisition, particularly in water-stressed periods.

\section{Water-use efficiency}

Water-use efficiencies (WUE) of invasive Australian acacias do not show significant differences in comparison with native vegetation in invaded areas (instantaneous gas exchange measures and long-term measures using foliar $\delta^{13} \mathrm{C}$ ratios as a proxy; Table 4). The WUE of invasive Australian acacias may however be situation- and species dependent, particularly when considering the differences in foliar types. One of the distinguishing characteristics of majority of the Australian acacias (c. 95\%; Maslin \& Stirton, 1997) is the fact that different foliar types exist between seedling and adult life stages (termed heteroblasty). Seedlings develop bipinnate compound leaves, which are replaced within weeks to years of emergence by modified petioles that enlarge and flatten to form simple leaf-like structures termed phyllodes (Walters \& Bartholomew, 1984; Boland et al., 2006). In water-limited conditions when a higher WUE would be desirable, phyllodes may be of particular advantage as these are thought to confer tolerance to drought because of their sclerophyllous nature (Elias, 1981; Pasquet-
Kok et al., 2010). Additionally, the sensitivity of stomatal closure in phyllodinous Australian acacias in response to increased vapour pressure deficits could contribute to phyllodes being more drought-tolerant in water-limited areas (Ullmann, 1989; Brodribb \& Hill, 1993; Pasquet-Kok et al., 2010). Low WUE, on the other hand, would exist when water is abundant and transpiration can occur freely. Thus, WUE is likely to be highly plastic. However, available data are from contexts in which water was readily available and hence marked differences between the WUE of Australian acacias and native species cannot be expected. Thus, investigations into the response of WUE of Australian acacias in comparison with native species under varying water availabilities are still needed.

\section{Nutrition}

Alien plant invasions can occur in a range of nutritional environments including low-resource environments (Funk \& Vitousek, 2007). This is also true of Australian acacias, which are often highly competitive in nutrient-poor Mediterraneantype ecosystems such as the CFR and Portuguese dune systems (Groves \& di Castri, 1991). Invasive Australian acacias are able to effectively acquire nutrients and have been shown to have
Table 4 Instantaneous water-use efficiency (WUE) measured by gas exchange analysis and long-term WUE determined from foliar $\delta^{13} \mathrm{C}$ of invasive Australian acacias in comparison with native species. Data collected by Kraaij \& Cramer (1999) are from a non-riparian field site in the high-rainfall season (August-September 1998) in the Cape Floristic Region (CFR), South Africa. Peperkorn et al. (2005) provide data from a greenhouse study in which plants were irrigated. Data derived from Crous (2010) are from riparian field sites located in the CFR, South Africa. Relative to natural vegetation, + indicates a higher WUE of Australian acacias, 0 indicates no significant difference and indicates a lower WUE.

\begin{tabular}{|c|c|c|c|c|c|}
\hline Acacia spp. & Native spp. & Water availability & Measure & Comparison & Reference \\
\hline \multirow[t]{4}{*}{ A. longifolia } & Protea repens & High - wet season & WUE & 0 & \multirow{4}{*}{$\begin{array}{l}\text { Kraaij \& Cramer, } \\
1999\end{array}$} \\
\hline & $\begin{array}{l}\text { Chrysanthemoides } \\
\text { monilifera }\end{array}$ & High - wet season & WUE & + & \\
\hline & Dodonaea viscosa & High - wet season & WUE & 0 & \\
\hline & $\begin{array}{l}\text { Leucadendron } \\
\text { salignum }\end{array}$ & High - wet season & WUE & + & \\
\hline A. longifolia & $\begin{array}{l}\text { Halimium } \\
\text { halimifolium }\end{array}$ & High - irrigated & WUE & 0 & $\begin{array}{l}\text { Peperkorn et al., } \\
2005\end{array}$ \\
\hline \multirow[t]{2}{*}{ A. mearnsii } & $\begin{array}{l}\text { Brabejum } \\
\text { stellatifolium }\end{array}$ & High - riparian & $\delta^{13} \mathrm{C}$ & 0 & \multirow[t]{2}{*}{ Crous, 2010} \\
\hline & $\begin{array}{l}\text { Metrosideros } \\
\text { angustifolia }\end{array}$ & High - riparian & $\delta^{13} \mathrm{C}$ & - & \\
\hline \multirow[t]{4}{*}{ A. saligna } & Protea repens & High - wet season & WUE & 0 & \multirow{4}{*}{$\begin{array}{l}\text { Kraaij \& Cramer, } \\
1999\end{array}$} \\
\hline & $\begin{array}{l}\text { Chrysanthemoides } \\
\text { monilifera }\end{array}$ & High - wet season & WUE & 0 & \\
\hline & Dodonaea viscosa & High - wet season & WUE & 0 & \\
\hline & $\begin{array}{l}\text { Leucadendron } \\
\text { salignum }\end{array}$ & High - wet season & WUE & + & \\
\hline
\end{tabular}


greater leaf $\mathrm{N}$ concentrations than native species in invaded regions, while $\mathrm{P}$ concentrations are slightly more variable (Table 5). Musil (1993) found that A. saligna also exhibited greater concentrations of $\mathrm{K}, \mathrm{Ca}$ and $\mathrm{Mg}$ than native fynbos species. Considering that Australian acacias themselves originate from some of the most nutrient-poor soils in the world (Young \& Young, 2001), it is not surprising that these species are able to effectively compete for nutrients, leading us to question whether these plants possess particular traits or mechanisms that enhance their competitive ability for nutrient acquisition and conservation.

\section{Nutrient acquisition}

Nutrient acquisition by plants is influenced by three major factors: root structure (including biomass, surface area and spatial distribution), soil nutrient availability and the ability of the plant to form specialized associations for nutrient acquisition (Lambers et al., 2008a). Root biomass can be preferentially allocated to enriched shallow soils and/or towards growing deeper roots to tap unused nutrient resources (Jobbágy \& Jackson, 2001; Lambers et al., 2008a; Craine, 2009). As discussed earlier, invasive Australian acacias allocate a greater percentage of biomass to both deep and shallow roots in comparison with native species in invaded regions (Table 3). Acacia roots may also be more plastic in response to soil nutrient availability than other species. For example, the RMR of A. longifolia almost doubled when nutrient concentrations were reduced compared with native Mediterranean dune species Halimium halimifolium and Pinus pinea (Peperkorn et al., 2005).

The availability of soil nutrients to a plant is dependent on soil moisture and the ability of the plant to increase available nutrient concentrations through the use of root exudates. Soil moisture strongly influences the diffusive flux of nutrients into the rhizosphere. Plants can alter soil moisture by redirecting available water resources via hydraulic redistribution (Burgess et al., 1998; Hawkins et al., 2009), potentially increasing the solubility and hence availability of nutrients to plant roots
(Jackson et al., 2000; Ryel, 2004; Hawkins et al., 2009). However, very little direct evidence for nutrient acquisition via hydraulic redistribution is available (Lambers et al., 2006), and this remains an untested possibility for invasive Australian acacias. Furthermore, transpirational water use by plants also drives nutrient mass flow (Barber, 1995), and transpiration is thus partially regulated by nutrient availability, particularly $\mathrm{N}$ (Raven et al., 2004; Cramer et al., 2008, 2009; Cernusak et al., 2010). Mass flow of nutrients requires adequate soil water to supply transpirational demand and hence operates at the expense of WUE (Barber, 1995; Tinker \& Nye, 2000; Raven et al., 2004; Cramer et al., 2009). For many species, a decrease in nutrient availability decreases WUE (Raven et al., 2004), as has also been observed for A. longifolia (Peperkorn et al., 2005) suggesting that a water-nutrient trade-off may occur. The fact that water is required for both diffusive and mass-flow mobility of nutrients in soil provides a powerful explanation for the interaction of these two resources in determining plant growth.

Soil nutrient concentrations can also be altered by plants actively extracting nutrients that are not readily available, through the release of root exudates such as carboxylates and phosphatases (Lambers et al., 2008a). In the highly invaded South African CFR, well-represented families such as Proteaceae and the Restionaceae commonly produce specialized cluster roots, which increase surface area for diffusion and exudate release (Lamont, 1982; Lambers et al., 2006). Cluster roots are efficient at acquiring nutrients, particularly $\mathrm{P}$ from low-concentration and sparingly soluble sources (Lambers et al., 2006). Invasive Australian acacias lack cluster roots and are thus unlikely to be able to access these more recalcitrant forms of soil P. Despite this, invasive Australian acacias still compete effectively for nutrients in the intrinsically nutrientpoor soils of the CFR (Table 5). This competition may be enhanced through the ability of plants to form symbiotic mycorrhizal associations for nutrient acquisition (Lambers et al., 2008a).

Mycorrhizal associations occur in $82 \%$ of higher land plants (Brundrett, 2002) and enhance nutrient (particularly P)

Table 5 Foliar $\mathrm{N}$ and $\mathrm{P}$ concentrations (mean $\mathrm{mg} \mathrm{g}^{-1} \pm \mathrm{SE}$ ) of Australian acacia species in comparison with native species from the invaded region. Significantly larger values $(P<0.05)$ in comparisons are in bold. ND indicates no available data. Available data stem from studies in the Cape Floristic Region (CFR), South Africa.

\begin{tabular}{|c|c|c|c|c|c|c|}
\hline Acacia spp. & {$[\mathrm{N}]$} & {$[\mathrm{P}]$} & Native spp. & {$[\mathrm{N}]$} & {$[\mathrm{P}]$} & Reference \\
\hline A. cyclops & $18.5 \pm 0.71$ & $2.58 \pm 0.10$ & Pterocelastrus tricuspidatus & $9.70 \pm 0.26$ & $6.31 \pm 0.47$ & Witkowski, 1991a \\
\hline A. longifolia & $9.94 \pm 0.98$ & ND & Protea repens & $2.38 \pm 0.56$ & ND & Kraaij \& Cramer, 1999 \\
\hline \multirow[t]{3}{*}{ A. saligna } & $13.31 \pm 2.66$ & ND & Chrysanthemoides monilifera & $4.06 \pm 0.42$ & ND & \\
\hline & & & Dodonaea viscosa & $5.04 \pm 0.56$ & ND & \\
\hline & & & Leucadendron salignum & $1.82 \pm 0.28$ & ND & \\
\hline A. saligna & $20.50 \pm 0.77$ & $1.01 \pm 0.07$ & Leucospermum parile & $7.90 \pm 0.31$ & $0.93 \pm 0.04$ & Witkowski, 1991a \\
\hline A. saligna & $25.00 \pm 3.57$ & $1.48+0.16$ & Protea repens & $18.00 \pm 2.04$ & $0.65+0.21$ & Witkowski, 1991b \\
\hline \multirow[t]{3}{*}{ A. saligna } & $14.29 \pm 0.14$ & $0.7 \pm 0.01$ & Ericoid & $12.75 \pm 0.7$ & $0.59 \pm 0.06$ & Musil, 1993 \\
\hline & & & Restioid & $7.56 \pm 0.14$ & $0.31 \pm 0.03$ & \\
\hline & & & Proteoid & $8.82 \pm 0.42$ & $0.59 \pm 0.03$ & \\
\hline
\end{tabular}


acquisition (Lambers et al., 2008b; Smith \& Read, 2008). Both arbuscular mycorrhizas (AM) and ectomycorrhizas (EM) are able to take up soluble P from the soil, but only EM are able to chemically release $\mathrm{P}$ from sorbed and organic complexes (Smith \& Read, 2008). Most Australian acacia species are able to form AM and possibly also EM associations (Reddell \& Warren, 1987). However, the relative importance of these associations for $\mathrm{P}$ uptake in acacias remains unclear. Hoffman \& Mitchell (1986) showed a positive correlation between AM colonization with plant biomass accumulation and $\mathrm{P}$ content of A. saligna seedlings in the CFR. In contrast, RodríguezEcheverría et al. (2009) found that despite significant colonization of A. longifolia roots by AM fungi in Mediterranean dune systems, no advantage in $\mathrm{P}$ acquisition was conferred. The benefits of EM and AM associations in Australian acacias must depend on the form and availability of $\mathrm{P}$ in the soil. The formation of mycorrhizal associations and the lack of cluster roots are likely to restrict the invasive Australian acacias to dependence on organic $\mathrm{P}$ and the more soluble forms of inorganic $\mathrm{P}$. This inability to acquire the sparingly soluble forms of P that cluster-rooted species (particularly Proteaceae, Restionaceae and Fabaceae) of the invaded CFR do may serve to limit invasions of Australian acacias on some extremely nutrient-impoverished sandstone-derived soils of the CFR.

Australian acacias are well known for their $\mathrm{N}_{2}$-fixation abilities (Levine et al., 2003). $\mathrm{N}_{2}$-fixing associations occur in most Australian acacias (Lawrie, 1981; Lee et al., 2006), which usually nodulate with common, but slow-growing Bradyrhizobium species (Lafay \& Burdon, 2001; Rodríguez-Echeverría et al., 2011). Associations with other nodulating species have also been reported, including Rhizobium, Ensifer, Mesorhizobium, Burkholderia, Phyllobacterium and Devosia species (Marsudi et al., 1999; Lafay \& Burdon, 2001; Hoque et al., 2011). Associations between acacias and their nodulating symbionts are highly complex and can be influenced by several biotic and abiotic factors (Thrall et al., 2000, 2007; Murray et al., 2001; Rodríguez-Echeverría et al., 2011). Nonetheless, invasive Australian acacias nodulate readily in both their native and non-native regions (reviewed in this volume by RodríguezEcheverría et al., 2011) and are considered prolific $\mathrm{N}_{2}$-fixing species (Lawrie, 1981). In coastal dunes of Portugal,
A. longifolia was more efficient at forming symbiotic associations with bacteria and fixed greater amounts of $\mathrm{N}$ than other co-occurring $\mathrm{N}_{2}$-fixing legumes (Ulex eurpaeus and Cytisus grandiflorus; Rodríguez-Echeverría et al., 2009). Similarly, comparing the $\delta^{15} \mathrm{~N}$ of $\mathrm{N}_{2}$-fixing plants to others with $\mathrm{N}_{2}$ fixation disrupted by $\mathrm{O}_{2}$ fumigation, Stock et al. (1995) found that A. saligna in the CFR relied almost completely on symbiotic $\mathrm{N}_{2}$ fixation, while A. cyclops growing on slightly more nutrient-rich soil obtained only $51 \%$ of its $\mathrm{N}$ budget from $\mathrm{N}_{2}$ fixation. The long-term post-fire persistence of invasive Australian acacias in the CFR is somewhat puzzling because few native $\mathrm{N}_{2}$-fixing legumes (especially reseeders) persist beyond their post-fire dominance (Kruger, 1983; Hoffmann et al., 1987; Cocks, 1994; Cramer, 2010). This lack of indigenous legume reseeder persistence has been ascribed to the post-fire decline in P availability (Power et al., 2010). These authors suggested that deep roots and excessive water consumption may contribute to Australian acacia persistence.

The $\mathrm{N}_{2}$-fixing capabilities of Australian acacias and their ability to persist in invaded regions result in a substantial inputs of $\mathrm{N}$-enriched litter, leading to an elevated soil $\mathrm{N}$ status (Table 6). However, the ability of an invader to fix $\mathrm{N}_{2}$ in itself does not necessarily translate to immediate alteration of the invaded system's nutrient cycling (Corbin \& D'Antonio, 2004). Instead, Yelenik et al. (2007) demonstrated that with Australian acacias, the combination of $\mathrm{N}_{2}$ fixation coupled with the slow decomposition rates associated with sclerophyllous phyllodes led to elevated soil $\mathrm{N}$ pools with long-term impacts for ecosystem nutrient cycling. Australian acacias are thus strong ecosystem engineers, and the lasting legacy of increased soil $\mathrm{N}$ following Australian acacia invasion often results in reinvasion by the same or other alien species (Stock et al., 1995; Marchante et al., 2004, 2008, 2009; Yelenik et al., 2004).

\section{Nutrient conservation}

The sclerophyllous nature of Australian acacia phyllodes translates to long-lived leaves and evergreen trees (Loveless, 1961; Turner, 1994a). The evolutionary drivers for this adaptation, whether drought tolerance or nutrient conservation, have been subject to much debate (Givnish, 1979; Turner,
Table 6 Litter biomass, litter $\mathrm{N}$ concentrations and soil $\mathrm{N}$ concentrations of Australian acacia invasions compared to uninvaded native vegetation in Portugal and in the Cape Floristic Region (CFR). Data for longer (20+ years) and shorter (10 years) invasion periods are shown for Portugal. A + indicates a significantly $(P<0.05)$ greater value associated with Australian acacias in comparison with native vegetation, 0 indicates no significant difference and ND indicates no data available.

\begin{tabular}{|c|c|c|c|c|c|}
\hline \multirow[b]{2}{*}{ Acacia spp. } & \multirow[b]{2}{*}{ Region } & \multicolumn{2}{|l|}{ Litter } & \multirow{2}{*}{$\frac{\text { Soil }}{[\mathrm{N}]}$} & \multirow[b]{2}{*}{ Reference } \\
\hline & & Biomass & {$[\mathrm{N}]$} & & \\
\hline \multirow[t]{2}{*}{ A. cyclops } & CFR & + & + & + & Witkowski, 1991b \\
\hline & CFR & ND & ND & + & Stock et al., 1995 \\
\hline \multirow[t]{3}{*}{ A. longifolia } & Portugal (20+ years) & + & + & + & Marchante et al., 2008 \\
\hline & Portugal (10 years) & + & + & 0 & \\
\hline & Portugal & ND & ND & + & Rodríguez-Echeverría et al., 2009 \\
\hline \multirow[t]{4}{*}{ A. saligna } & CFR & + & + & + & Witkowski, 1991b \\
\hline & CFR & ND & ND & + & Musil, 1993 \\
\hline & CFR & ND & ND & + & Stock et al., 1995 \\
\hline & CFR & + & + & + & Yelenik et al., 2004, 2007 \\
\hline
\end{tabular}


1994b; Pasquet-Kok et al., 2010). In nutrient-rich environments, the common drought-tolerance adaptation is drought deciduousness (Mooney \& Dunn, 1970). However, in nutrientpoor environments, drought deciduousness would lead to the costly loss of limited nutrients. Thus, it is thought that sclerophyllous, long-lived phyllodes evolved to enhance nutrient conservation in response to nutrient limitations (Beadle, 1966; Specht \& Rundel, 1990) with drought tolerance and unpalatability being associated with the sclerophyllous nature of phyllodes.

Extended leaf longevity of Australian acacias would, however, not be a marked advantage when invading other sclerophyllous vegetation with similar nutrient-retention characteristics. For example, leaf longevity of Australian acacias (mean years \pm SE; $1.84 \pm 0.28$; Wright et al., 2002) did not differ significantly $(P>0.05)$ from that of native CFR vegetation (mean $\pm \mathrm{SE}$; $2.62 \pm 0.31$; Midgley \& Enright, 2000). Sclerophylly, although not different from that of the invaded flora, when coupled with other traits such as $\mathrm{N}_{2}$ fixation may contribute to the success of Australian acacias. Interestingly, the non-phyllodinous and relatively non-sclerophyllous (i.e. high SLA) invasive Australian acacia, A. mearnsii, has particularly long-lived bipinnate leaves, which turn brown during drought but recover subsequent to the onset of rain (Orians \& Milewski, 2007) possibly acting to conserve nutrients over multiple seasons.

Heteroblasty thus confers the advantage of different growth strategies between juvenile and adult life stages and between different environmental circumstances (Pasquet-Kok et al., 2010). As young seedlings, acacias benefit from the high relative growth rate associated with bipinnate leaflets (Witkowski, 1991b; Hansen, 1996; Evans et al., 2000; Pasquet-Kok et al., 2010). The phyllodinous species then switch to slowergrowing, longer-lived and hence nutrient-conserving phyllodes (Ullmann, 1989; Orians \& Milewski, 2007; Pasquet-Kok et al., 2010). Using acacia invasions in South Africa as a case study, the distinct advantage of phyllodes in nutrient-poor and summer-drought regions can be inferred by the relative success of phyllodinous species in the mediterranean climate and nutrient-poor fynbos biome (Rouget et al., 2004; Table 7, e.g. A. pycnantha). In contrast, the non-phyllodinous species (e.g. A. mearnsii and A. dealbata) are more successful as invaders in more mesic environments or along water courses (Rouget et al., 2004; Table 7) where nutrients and water are not as limiting.

Plants can also conserve nutrients through the remobilization of limiting nutrients prior to leaf abscission (Eckstein et al., 1999; Wright et al., 2002), acting to increase the mean residence time of nutrients in the plant. Australian acacias remobilize nutrients prior to leaf abscission, especially when the specific nutrient is limiting in the system (Witkowski, 1991a). In the South African CFR, A. saligna remobilized a large proportion $(71 \%)$ of its leaf $\mathrm{P}$, an amount significantly greater than that of the comparison native species Leucospermum parile (48\%; Witkowski, 1991a). However, studies assessing remobilization efficiencies of these plants in comparison with natives in invaded regions are scarce. Specht (1981) and Langkamp \& Dalling (1982) showed that remobilization of nutrients by invasive Australian acacias was not particularly different to that of other Australian species from nutrient-impoverished areas (e.g. Banksia ornata and Acacia holosericea) and is thus not a trait unique to the invasive Australian acacias.

\section{IMPLICATIONS FOR FUTURE INVASION RISK}

Global change is expected to alter resource distribution and availabilities through changes to climate, nutrient cycling (through nutrient deposition), disturbance regimes and landuse practices. These changes are generally predicted to favour the increase and impacts of alien plant invasions around the globe (Dukes \& Mooney, 1999; Thuiller et al., 2007; Vilà

Table 7 Percentage of records of the eight most widespread invasive Australian acacia species found in each biome in South Africa. Species are ranked from most prevalent to least prevalent according to the percentage of quarter degree squares occupied, as recorded in the South African Plant Invaders Atlas (SAPIA; Henderson, 2007). The percentage of the total records that were found along water courses is also listed. Foliage indicates whether adult plants have leaves (L) or phyllodes (P). The biome in which each species had the highest occurrence is in bold.

\begin{tabular}{|c|c|c|c|c|c|c|c|c|}
\hline \multirow[b]{2}{*}{ Acacia spp. } & \multirow[b]{2}{*}{ Foliage } & \multirow[b]{2}{*}{ QDS (\%) } & \multicolumn{6}{|c|}{ Percentage of records found in each biome* } \\
\hline & & & Savanna & Fynbos & Grassland & Nama karoo & Succulent karoo & Water courses \\
\hline A. mearnsii & $\mathrm{L}$ & 21 & 27 & 33 & 38 & 0 & 1 & 36 \\
\hline A. dealbata & $\mathrm{L}$ & 12 & 12 & 2 & 85 & 0 & 0 & 50 \\
\hline A. saligna & $\mathrm{P}$ & 8 & 9 & 83 & 0 & 0 & 7 & 35 \\
\hline A. cyclops & $\mathrm{P}$ & 8 & 16 & 74 & 0 & 0 & 10 & 19 \\
\hline A. melanoxylon & $\mathrm{P}$ & 7 & 15 & 62 & 23 & 0 & 0 & 27 \\
\hline A. longifolia & $\mathrm{P}$ & 5 & 18 & 73 & 9 & 0 & 1 & 36 \\
\hline A. decurrens & $\mathrm{L}$ & 5 & 16 & 0 & 84 & 0 & 0 & 13 \\
\hline A. pycnantha & $\mathrm{P}$ & 2 & 3 & 97 & 0 & 0 & 0 & 4 \\
\hline
\end{tabular}

*Biomes classified according to Rutherford, 1997. 
Table 8 Response of net assimilation rate (NAR), relative growth rate (RGR), total plant biomass, stomatal conductance and total N fixed of invasive Australian acacias under elevated $\mathrm{CO}_{2}$ levels (700 ppm). Foliage indicates whether adult plants have leaves $(\mathrm{L})$ or phyllodes $(\mathrm{P})$. + indicates an increase, 0 indicates no significant difference and - indicates a decrease in comparison with current ambient $\mathrm{CO}_{2}$ levels (350 ppm), while ND is no data available.

\begin{tabular}{|c|c|c|c|c|c|c|}
\hline Acacia spp. & Foliage & $\mathrm{NAR}^{\star} \dagger$ & $\mathrm{RGR}^{*} \dagger$ & Biomass $^{*} \dagger$ & Conductance & Total N fixed $\dagger$ \\
\hline A. dealbata & $\mathrm{L}$ & + & + & + & 0 & 0 \\
\hline A. implexa & $\mathrm{P}$ & + & + & + & + & + \\
\hline A. irrorata & $\mathrm{L}$ & + & + & + & - & + \\
\hline A. mearnsii & $\mathrm{L}$ & + & + & + & - & + \\
\hline A. melanoxylon & $\mathrm{P}$ & + & + & + & - & + \\
\hline A. saligna & $\mathrm{P}$ & + & + & + & 0 & ND \\
\hline
\end{tabular}

*Atkin et al., 1999; †Schortemeyer et al., 2002; †Evans et al., 2000.

et al., 2007), although there are exceptions (Richardson et al., 2000, 2010). Invaders may be able to benefit from these changes either by being stronger competitors for resources or because of decreased competition from stressed native species (Thuiller et al., 2007), as suggested by Davis et al. (2000) in the 'Fluctuating Resource Hypothesis'. Under elevated $\left[\mathrm{CO}_{2}\right]$ environments, Australian acacias have higher net assimilation rates, leading to increased relative growth rate and plant biomass (Table 8). Plants also showed a decrease conductance and hence increased WUE (Table 8). Moreover, Australian acacias also fixed greater amounts of $\mathrm{N}_{2}$ under elevated $\left[\mathrm{CO}_{2}\right]$ (Table 8 ) as has also been shown for several other $\mathrm{N}_{2}$-fixing species (Thomas et al., 1991; Vogel \& Curtis, 1995; Polley et al., 1997). These studies indicate that with continuing global change, Australian acacia species may well have increased invasive competitive abilities for resource acquisition, further enhancing their invasion success.

\section{CONCLUSION}

To synthesize, the height and biomass of invasive Australian acacias in invaded ranges far exceeds that of the native species both as seedlings and as adults. Initial high relative growth rates allow acacias to overtop the native vegetation and outcompete natives for light. Greater below-ground investment combined with mycorrhizal and $\mathrm{N}_{2}$-fixing symbioses enables access to both water and nutrients needed to sustain growth. Furthermore, sclerophylly and the greater ability to remobilize limiting nutrients enable efficient nutrient conservation. Thus, no one ecophysiological or morphological trait can be identified as the primary driver of invasion success. Instead, it would appear that multiple traits act synergistically to confer competitive advantage. Understanding the traits used by invasive Australian acacias to acquire, utilize and conserve essential resources will allow us to better understand how resource distribution and availability influence invasions across a landscape. Incorporating greater edaphic and biotic components of the invaded environments into current species distribution models would thus enhance predictive power of models that are currently mostly limited to the use of only abiotic factors and limited soil characteristics (Meier et al.,
2010). This is vital for predicting alien plant distributions, under both current and future global change scenarios.

\section{ACKNOWLEDGEMENTS}

We thank the Oppenheimer Memorial Trust, Stellenbosch University, the Working for Water Programme and the DSTNRF Centre for Invasion Biology for financial support of the workshop (Stellenbosch, South Africa, October 2010) at which this paper was presented. T. Morris acknowledges the Schlumberger Foundation 'Faculty for the Future' Fellowship and the University of Colorado United Government of Graduate Students for funding attendance of the workshop.

\section{REFERENCES}

Atkin, O.K., Schortemeyer, M., McFarlane, N. \& Evans, J.R. (1999) The response of fast- and slow-growing Acacia species to elevated atmospheric $\mathrm{CO}_{2}$ : an analysis of the underlying components of relative growth rate. Oecologia, 120, 544-554.

Baker, H.G. (1974) The evolution of weeds. Annual Review of Ecology and Systematics, 5, 1-24.

Barber, S.A. (1995) Soil nutrient bioavailability: a mechanistic approach. John Wiley \& Sons, New York.

Beadle, N.C.W. (1966) Soil phosphate and its role in molding segments of the Australian flora and vegetation, with special emphasis to xeromorphy and scleromorphy. Ecology, 47, 992-1007.

Boland, D.J., Brooker, M.I.H., Chippendale, G.M., Hall, N., Hyland, B.P.M., Johnston, R.D., Kleinig, D.A., McDonald, M.W. \& Turner, J.D. (2006) Forest trees of Australia. CSIRO publishing, Collingwood, Australia.

Brodribb, T. \& Hill, R.S. (1993) A physiological comparison of leaves and phyllodes in Acacia melanoxylon. Australian Journal of Botany, 41, 293-305.

Brundrett, M.C. (2002) Coevolution of roots and mycorrhizas of land plants. New Phytologist, 154, 275-304.

Burgess, S.S.O., Adams, M.A., Turner, N.C. \& Ong, C.K. (1998) The redistribution of soil water by tree root systems. Oecologia, 115, 306-311. 
Canadell, J., Jackson, R.B., Ehleringer, J.R., Mooney, H.A., Sala, O.E. \& Schulze, E.-D. (1996) Maximum rooting depth of vegetation types at the global scale. Oecologia, 108, 583595.

Carruthers, J., Robin, L., Hattingh, J.P., Kull, C.A., Rangan, H. \& van Wilgen, B.W. (2011) A native at home and abroad: the history, politics, ethics and aesthetics of acacias. Diversity and Distributions, 17, 810-821.

Castro-Díez, P., Godoy, O., Saldaña, A. \& Richardson, D.M. (2011) Predicting invasiveness of Australian acacias on the basis of their native climatic affinities, life-history traits and human use. Diversity and Distributions, 17, 934-945.

Cernusak, L.A., Winter, K. \& Turner, B.L. (2010) Leaf nitrogen to phosphorus ratios of tropical trees: experimental assessment of physiological and environmental controls. New Phytologist, 185, 770-779.

Cocks, M.P. (1994) The ecology and nitrogen-fixing ability of selected Aspalathus spp. in fynbos ecosystems. PhD thesis, University of Cape Town, South Africa.

Corbin, J.D. \& D'Antonio, C.M. (2004) Effects of exotic species on soil nitrogen cycling: implications for restoration. Weed Technology, 18, 1464-1467.

Cordell, S., Cabin, R.J. \& Hadway, L.J. (2002) Physiological ecology of native and alien dry forest shrubs in Hawaii. Biological Invasions, 4, 387-396.

Craine, J.M. (2009) Resource strategies of wild plants. Princeton University Press, Princeton.

Cramer, M.D. (2010) Phosphate as a limiting resource: introduction. Plant and Soil, 334, 1-10.

Cramer, M.D., Hoffmann, V. \& Verboom, G.A. (2008) Nutrient availability moderates transpiration in Ehrharta calycina. New Phytologist, 179, 1048-1057.

Cramer, M.D., Hawkins, H.-J. \& Verboom, G.A. (2009) The importance of nutritional regulation of plant water flux. Oecologia, 161, 15-24.

Crawley, M.J. (1997) Plant ecology, 2nd edn. Blackwell Science Ltd., Oxford.

Crous, C.J. (2010) Vulnerability of selected native and invasive woody species to streamflow variability in Western Cape fynbos riparian ecotones. MSc thesis. Stellenbosch University, South Africa.

Davis, M.A., Grime, J.P. \& Thompson, K. (2000) Fluctuating resources in plant communities: a general theory of invisibility. Journal of Ecology, 88, 528-534.

Dukes, J.S. \& Mooney, H.A. (1999) Does global change increase the success of biological invaders? Trends in Ecology \& Evolution, 14, 135-139.

Dye, P., Moses, G., Vilakazi, P., Ndlela, R. \& Royappen, M. (2001) Comparative water use of wattle thickets and indigenous plant communities at riparian sites in the Western Cape and KwaZulu-Natal. Water Sa, 27, 529538.

Eckstein, R.L., Karlsson, P.S. \& Weih, M. (1999) Leaf life span and nutrient resorption as determinants of plant nutrient conservation in temperate-arctic regions. New Phytologist, 143, 177-189.
Elias, T.S. (1981) Mimosoideae. Advances in legume systematics (ed. by R.M. Polhill and P.H. Raven), pp. 143-151. Royal Botanical Gardens Kew, Kew.

Elton, C.S. (1958) The ecology of invasions by animals and plants. Methuen, London.

Enright, W.D. (2000) The effect of terrestrial invasive alien plants on water scarcity in South Africa. Physics and Chemistry of the Earth (B), 25, 237-242.

Evans, J.R., Schortemeyer, M., McFarlane, N. \& Atkin, O.K. (2000) Photosynthetic characteristics of 10 Acacia species grown under ambient and elevated atmospheric $\mathrm{CO}_{2}$. Australian Journal of Plant Physiology, 27, 13-25.

Fatoki, O.B. (2007) Monitoring the re-growth rate of alien vegetation after fire on Agulhas Plain, South Africa. Honours thesis, Stellenbosch University, South Africa.

Funk, J.L. \& Vitousek, P.M. (2007) Resource-use efficiency and plant invasion in low-resource systems. Nature, 446, 10791081.

Gibson, M.R., Richardson, D.M., Marchante, E., Marchante, H., Rodger, J.G., Stone, G.N.N., Byrne, M., Fuentes-Ramírez, A., George, N., Harris, C., Johnson, S.D., Le Roux, J.J., Murphy, D.J., Pauw, A., Prescott, M.N. \& Wandrag, E.M. (2011) Reproductive ecology of Australian acacias: fundamental mediator of invasive success? Diversity and Distributions, 17, 911-933.

Givnish, T.J. (1979) On the adaptive significance of leaf form. Topics in plant population biology (ed. by O.T. Solbrig, S. Jain, G.B. Johnson and P.H. Raven), pp. 375-407. Columbia University Press, New York.

Griffin, A.R., Midgley, S.J., Bush, D., Cunningham, P. \& Rinaudo, A.T. (2011) Global plantings and utilisation of Australian acacias-past, present and future. Diversity and Distributions, 17, 837-847.

Groves, R.H. \& di Castri, K.J. (1991) Biogeography of Mediterranean invasions. Cambridge University Press, Cambridge.

Hansen, D.H. (1996) Establishment and persistence characteristics in juvenile leaves and phyllodes of Acacia koa (Leguminosae) in Hawaii. International Journal of Plant Sciences, 157, 123-128.

Hawkins, H.-J., Hettasch, H., West, A.G. \& Cramer, M.D. (2009) Hydraulic redistribution by Protea 'Sylvia' (Proteaceae) facilitates soil water replenishment and water acquisition by an understory grass and shrub. Functional Plant Biology, 36, 752-760.

Henderson, L. (2007) Invasive, naturalized and casual alien plants in southern Africa: a summary based on the Southern African Plant Invaders Atlas (SAPIA). Bothalia, 37, 215248.

Hoffman, M.T. \& Mitchell, D.T. (1986) Root morphology of legume spp. in the south-western Cape and the relationship of vesicular-arbuscular mycorrhizas with dry mass and phosphorus content of Acacia saligna seedlings. South African Journal of Botany, 52, 316-320.

Hoffmann, M.T., Moll, E.J. \& Boucher, C. (1987) Post-fire succession at Pella, a South African lowland fynbos site. South African Journal of Botany, 53, 370-374. 
Holmes, P.M. (1989) Decay rates for buried Acacia seed populations of different density. South African Journal of Botany, 55, 299-303.

Holmes, P.M. \& Cowling, R.M. (1997) The effects of invasion by Acacia saligna on the guild structure and regeneration capabilities of South African fynbos shrublands. Journal of Applied Ecology, 34, 317-332.

Hoque, M.S., Broadhurst, L.M. \& Thrall, P.H. (2011) Genetic characterization of root nodule bacteria associated with Acacia salicina and A. stenophylla (Mimosaceae) across south-eastern Australia. International Journal of Systematic and Evolutionary Microbiology, 61, 299-309.

Jackson, R.B., Sperry, J.S. \& Dawson, T.E. (2000) Root water uptake and transport: using physiological processes in global predictions. Trends in Plant Science, 5, 482-488.

Jobbágy, E.G. \& Jackson, R.B. (2001) The distribution of soil nutrients with depth: global patterns and the imprint of plants. Biogeochemistry, 53, 51-77.

Joffre, R., Rambal, S. \& Damesin, C. (2007) Functional attributes in Mediterranean-type ecosystems. Functional plant ecology, 2nd edn. (ed. by F.I. Pugnaire and F. Valladares), pp. 285-312. Marcel Dekker, New York.

Knight, A., Blott, K., Portelli, M. \& Hignett, C. (2002) Use of tree and shrub belts to control leakage in three dryland cropping environments. Australian Journal of Agricultural Research, 53, 571-586.

Kraaij, T. \& Cramer, M.D. (1999) Do the gas exchange characteristics of alien acacias enable them to successfully invade the fynbos? South African Journal of Botany, 65, 232-238.

Kruger, F.J. (1983) Plant community diversity and dynamics in relation to fire. Mediterranean-type ecosystems: the role of nutrients (ed. by F.J. Kruger, D.T. Mitchell and J.U. Jarvis), pp. 466-472. Springer, Berlin.

Kull, C.A., Shackleton, C.A., Cunningham, P. et al. (2011) Adoption, use, and perception of Australian acacias around the world. Diversity and Distributions, 17, 822-836.

Lafay, B. \& Burdon, J.J. (2001) Small-subunit rRNA genotyping of rhizobia nodulating Australian Acacia spp. Applied and Environmental Microbiology, 67, 396-402.

Lambers, H., Shane, M.W., Cramer, M.D., Pearse, S.J. \& Veneklaas, E.J. (2006) Root structure and functioning for efficient acquisition of phosphorus: matching morphological and physiological traits. Annals of Botany, 98, 693-713.

Lambers, H., Raven, J.A., Shaver, G.R. \& Smith, S.E. (2008a) Plant nutrient-acquisition strategies change with soil age. Trends in Ecology and Evolution, 23, 95-103.

Lambers, H., Pons, T.L. \& Chapin, F.S., III. (2008b) Plant physiological ecology, 2nd edn. Springer-Verlag, New York.

Lamont, B. (1982) Mechanisms for enhancing nutrient uptake in plants, with particular reference to Mediterranean South Africa and Western Australia. Botanical Review, 48, 597-689.

Langkamp, P.J. \& Dalling, M.J. (1982) Nutrient cycling in a stand of Acacia holosericea A. Cunn ex. G. Don. II. Phosphorus and mycorrhizal associations. Australian Journal of Botany, 30, 107-119.
Lawrie, A.C. (1981) Nitrogen fixation by native Australian legumes. Australian Journal of Botany, 29, 143-157.

Le Maitre, D.C. (2004) Predicting invasive species impacts on hydrological processes: the consequences of plant physiology for landscape processes. Weed Technology, 18, 1408-1410.

Le Maitre, D.C., van Wilgen, B.W., Chapman, R.A. \& McKelly, D.H. (1996) Invasive plants and water resources in the Western Cape Province, South Africa: modelling the consequences of a lack of management. Journal of Applied Ecology, 33, 161-172.

Le Maitre, D.C., Versfeld, D.B. \& Chapman, R.A. (2000) The impact of invading alien plants on surface water resources in South Africa: a preliminary assessment. Water SA, 26, 397-408.

Le Maitre, D.C., van Wilgen, B.W., Gelderblom, C.M., Bailey, C., Chapman, R.A. \& Nel, J.A. (2002) Invasive alien trees and water resources in South Africa: case studies of the costs and benefits of management. Forest Ecology and Management, 160, 143-159.

Le Maitre, D.C., Gaertner, M., Marchante, E.M., Ens, E.-J., Holmes, P.M., Pauchard, A., O’Farrell, J.O., Rogers, A.M., Blanchard, R., Blignaut, J. \& Richardson, D.M. (2011) Impacts of introduced Australian acacias: implications for management and restoration. Diversity and Distributions, 17, $1015-1029$.

Lee, Y.K., Lee, D.K., Woo, S.Y., Park, P.S., Jang, Y.H. \& Abraham, E.R.G. (2006) Effect of Acacia plantations on net photosynthesis, tree species composition, soil enzyme activities, and microclimate on Mt. Makiling. Photosynthetica, 44, 299-308.

Levine, J.M., Vilà, M., D’Antonio, C.M., Dukes, J.S., Grigulis, K. \& Lavorel, S. (2003) Mechanisms underlying the impacts of exotic plant invasions. Proceedings of the Royal B, 270, 775-781.

Lockwood, J.L., Cassey, P. \& Blackburn, T. (2005) The role of propagule pressure in explaining species invasions. Trends in Ecology and Evolution, 20, 223-228.

Loveless, A.R. (1961) A nutritional interpretation of sclerophylly based on differences in the chemical composition of sclerophyllous and mesophytic leaves. Annals of Botany, 25, 168-184.

Lowe, S., Browne, M., Boudjelas, S. \& De Poorter, M. (2000) 100 of the world's worst invasive alien species A selection from the Global Invasive Species Database. Invasive Species Specialist Group (ISSG), IUCN, Gland, Switzerland.

MacArthur, R.H. (1970) Species packing and competitive equilibrium for many species. Theoretical Population Biology, $1,1-11$.

Marchante, H., Marchante, E. \& Freitas, H. (2003) Invasion of the Portuguese dune ecosystem by the exotic species Acacia longifolia (Andrews) Willd: effects at community level. Plant invasions: ecological threats and management solutions (ed. by L.E. Child, J.H. Brock, G. Brundu, K. Prach, P. Pyšek, P.M. Wade and M. Williamson), pp. 75-85. Backhuys Publishers, Leiden, The Netherlands.

Marchante, H.S., Marchante, E.M., Buscardo, E., Maia, J. \& Freitas, H. (2004) Recovery potential of dune ecosystems 
invaded by an exotic Acacia species (Acacia longifolia). Weed Technology, 18, 1427-1433.

Marchante, E., Kjøller, A., Struwe, S. \& Freitas, H. (2008) Short- and long-term impacts of Acacia longifolia invasion on the belowground processes of a Mediterranean coastal dune ecosystem. Applied Soil Ecology, 40, 210-217.

Marchante, E., Kjøller, A., Struwe, S. \& Freitas, H. (2009) Soil recovery after removal of the $\mathrm{N}_{2}$-fixing invasive Acacia longifolia: consequences for ecosystem restoration. Biological Invasions, 11, 813-823.

Marsudi, N.D.S., Glenn, A.R. \& Dilworth, M.J. (1999) Identification and characterization of fast- and slow-growing root nodule bacteria from South-Western Australian soils able to nodulate Acacia saligna. Soil Biology and Biochemistry, 31, 1229-1238.

Maslin, B.R. \& Stirton, C.H. (1997) Generic and infrageneric classification in Acacia (Leguminosae: Mimosoideae): a list of critical species on which to build a comparative data set. Bulletin of the International Group for the Study of Mimosoideae, 20, 22-44.

Meier, E.S., Kienast, F., Pearman, P.B., Svenning, J., Thuiller, W., Araújo, M.B., Guisan, A. \& Zimmermann, N.E. (2010) Biotic and abiotic variables show little redundancy in explaining tree species distributions. Ecography, 33, 1038-1048.

Midgley, J.J. \& Enright, N.J. (2000) Serotinous species show correlation between retention time for leaves and cones. Journal of Ecology, 88, 348-351.

Midgley, G.F., Rutherford, M.C., Davis, G.W. \& Bösenberg, J. de W. (1992) Photosynthetic response of heliophilous Rhus species to environmental modification by invasive shrubs. Functional Ecology, 6, 334-345.

Miller, J.P., Murphy, D.J., Brown, G.K., Richardson, D.M. \& González-Orozcol, C.E. (2011) The evolution and phylogenetic placement of invasive Australian Acacia species. Diversity and Distributions, 17, 848-860.

Milton, S.J. (1980) Australian acacias in the south-western Cape: pre-adaptation, predation and success. Proceedings of the 3rd National Weed Conference of Southern Africa (ed. by A.L.P. Cairns and S. Neser), pp. 69-78. Stellenbosch.

Milton, S.J. \& Siegfried, W.R. (1981) Above-ground biomass of Australian acacias in the southern Cape, South Africa. South African Journal of Botany, 47, 701-716.

Mooney, H.A. \& Dunn, E.L. (1970) Photosynthetic systems of Mediterranean-climate shrubs and trees of California and Chile. American Naturalist, 104, 447-453.

Murray, B.R., Thrall, P.H. \& Woods, M.J. (2001) Acacia species and rhizobial interactions: implications for restoration of native vegetation. Ecological Management and Restoration, 2, 213-219.

Musil, C.F. (1993) Effect of invasive Australian acacias on the growth and nutrient chemistry of South African lowland fynbos. Journal of Applied Ecology, 30, 361-372.

Orians, G.H. \& Milewski, A.V. (2007) Ecology of Australia: the effects of nutrient-poor soils and intense fires. Biological Review, 82, 393-423.
Osunkoya, O.O., Othman, F.E. \& Kahar, R.S. (2005) Growth and competition between seedlings of an invasive plantation tree, Acacia mangium, and those of a native Borneo heathforest species, Melastoma beccarianum. Ecological Restoration, 20, 205-214.

Pasquet-Kok, J., Creese, C. \& Sack, L. (2010) Turning over a new 'leaf ': multiple functional significances of leaves versus phyllodes in Hawaiian Acacia koa. Plant, Cell and Environment, 33, 2084-2100.

Pate, J.S., Jeschke, W.D. \& Aylward, M.J. (1995) Hydraulic architecture and xylem structure of the dimorphic root systems of south-west Australian species of Proteaceae. Journal of Experimental Botany, 46, 907-915.

Peperkorn, R., Werner, C. \& Beyschlag, W. (2005) Phenotypic plasticity of an invasive acacia versus two native Mediterranean species. Functional Plant Biology, 32, 933944.

Polley, H.W., Johnson, H.B. \& Mayeux, H.S. (1997) Leaf physiology, production, water use, and nitrogen dynamics of the grassland invader Acacia smallii at elevated $\mathrm{CO}_{2}$ concentrations. Tree Physiology, 17, 89-96.

Power, S.C., Cramer, M.D., Verboom, G.A. \& Chimphango, S.B.M. (2010) Does phosphate acquisition constrain legume persistence in the fynbos of the Cape Floristic Region? Plant and Soil, 334, 33-46.

Pyšek, P. \& Richardson, D.M. (2007) Traits associated with invasiveness in alien plants: where do we stand? Biological invasions, (ed. by W. Nentwig), pp. 97-125. Springer, Berlin.

Rascher, K.G., Werner, C., Máguas, C. \& Correia, O. (2009) Tracing seasonal changes in water use of an invasive Acacia and a native pine in Southern Portugal by measurement of sap flow. Acta Horticulturae, 846, 209-216.

Raven, J.A., Handley, L.L. \& Wollenweber, B. (2004) Plant nutrition and water use efficiency. Water use efficiency in plant biology (ed. by M.S. Bacon), pp. 171-197. Blackwell Scientific Publications, Oxford.

Reddell, P. \& Warren, R. (1987) Inoculation of acacias with mycorrhizal fungi: potential benefits. Proc. No. 16 ACIAR on Australian acacias in developing countries (ed. by J.W. Turnbull), pp. 50-53. Canberra, Australia.

Rejmánek, M. \& Richardson, D.M. (1996) What attributes make some plant species more invasive? Ecology, 77, 16551661.

Rejmánek, M., Richardson, D.M., Higgins, S.I., Pitcairn, M.J. \& Grotkopp, E. (2005) Ecology of invasive plants: state of the art. Invasive alien species: a new synthesis (ed. by H.A. Mooney, R.N. Mack, J.A. McNeely, L.E. Neville, P.J. Schei and J.K. Waage), pp. 104-161. Island Press, Washington, DC.

Richardson, D.M. \& Kluge, R.L. (2008) Seed banks of invasive Australian Acacia species in South Africa: role in invasiveness and options for management. Perspectives in Plant Ecology, Evolution and Systematics, 10, 161-177.

Richardson, D.M. \& Rejmánek, M. (2011) Trees and shrubs as invasive alien species - a global review. Diversity and Distributions, 17, 788-809. 
Richardson, D.M., Macdonald, I.A.W. \& Forsyth, G.G. (1989) Reductions in plant species richness under stands of alien trees and shrubs in the fynbos biome. South African Forestry Journal, 149, 1-8.

Richardson, D.M., Bond, W.J., Dean, R.J., Higgins, S.I., Midgley, G.F., Milton, S.J., Powrie, L.W., Rutherford, M.C., Samways, M.J. \& Schulze, R.E. (2000) Invasive alien organisms and global change: a South African Perspective. Invasive species in a changing world (ed. by H.A. Mooney and R.J. Hobbs), pp. 303-349. Island Press, Washington, DC.

Richardson, D.M., Holmes, P.M., Esler, K.J., Galatowitsch, S.M., Stromberg, J.C., Kirkman, S.P., Pyšek, P. \& Hobbs, R.J. (2007) Riparian vegetation: degradation, alien plant invasions and restoration prospects. Diversity and Distributions, 13, 126-139.

Richardson, D.M., Iponga, D.M., Roura-Pascual, N., Krug, R.M., Milton, S.J., Hughes, G.O. \& Thuller, W. (2010) Accommodating scenarios of climate change and management in modelling the distribution of the invasive tree Schinus molle in South Africa. Ecography, 33, 1049-1061.

Richardson, D.M., Carruthers, J., Hui, C., Impson, F.A.C., Robertson, M.P., Rouget, M., Le Roux, J.J. \& Wilson, J.R.U. (2011) Human-mediated introductions of Australian acaciasa global experiment in biogeography. Diversity and Distributions, 17, 771-787.

Robinson, D. (2004) Scaling the depths: below-ground allocation in plants, forests and biomes. Functional Ecology, 18, 290-295.

Roché, B.F., Roché, C.T. \& Chapman, R.C. (1994) Impacts of grassland habitat on yellow starthistle (Centaurea solstitialis L.) invasion. Northwest Science, 68, 86-96.

Rodríguez-Echeverría, S., Crisóstomo, J.A., Nabais, C. \& Freitas, H. (2009) Belowground mutualists and the invasive ability of Acacia longifolia in coastal dunes of Portugal. Biological Invasions, 11, 651-661.

Rodríguez-Echeverría, S., Le Roux, J., Crisóstomo, J. \& Ndlovu, J. (2011) Jack-of-all-trades and master of many? How does associated rhizobial diversity influence the colonization success of Australian Acacia species? Diversity and Distributions, 17, 946-957.

Rouget, M., Richardson, D.M., Cowling, R.M., Lloyd, J.W. \& Lombard, A.T. (2003) Current patterns of habitat transformation and future threats to biodiversity in the Cape Floristic Region, South Africa. Biological Conservation, 112, 63-85.

Rouget, M., Richardson, D.M., Nel, J.L., Le Maitre, D.C., Egoh, B. \& Mgidi, T. (2004) Mapping the potential ranges of major plant invaders in South Africa, Lesotho and Swaziland using climatic suitability. Diversity and Distributions, 10, 475-484.

Rutherford, M.C. (1997) Categorization of biomes. Vegetation of southern Africa (ed. by R.M. Cowling, D.M. Richardson and S.M. Pierce), pp. 91-98. Cambridge University Press, Cambridge.

Rutherford, M.C. \& Bösenberg, J. de W. (1988) Some responses of indigenous Western Cape vegetation to the Australian invasive, Acacias cyclops. Time scales and water stress (ed. by F. Di Castri, C. Floret, S. Rambal and J. Roy), pp. 631-636. IUBS, Paris.

Ryel, R.J. (2004) Hydraulic redistribution. Progress in Botany, 65, 413-435.

Schortemeyer, M., Atkin, O.K., McFarlane, N. \& Evans, J.R. (2002) $\mathrm{N}_{2}$ fixation by Acacia species increases under elevated atmospheric $\mathrm{CO}_{2}$. Plant, Cell and Environment, 25, 567-579.

Shenk, H.J. \& Jackson, R.B. (2002) Rooting depths, lateral root spreads and below-ground/above ground allometries of plants in water-limited ecosystems. Journal of Ecology, 90, 480-494.

Smith, S.E. \& Read, D.J. (2008) Mycorrhizal symbiosis, 3rd edn. Academic Press, London.

Specht, R.L. (1981) Nutrient release from decomposing leaf litter of Banksia ornata, Dark Island heathland, South Australia. Australian Journal of Ecology, 6, 59-63.

Specht, R.L. \& Rundel, P.W. (1990) Sclerophylly and foliar nutrient status of Mediterranean-climate plant communities in Southern Australia. Australian Journal of Botany, 38, 459474.

Stock, W.D., Wienand, K.T. \& Baker, A.C. (1995) Impacts of invading $\mathrm{N}_{2}$-fixing Acacia species on patterns of nutrient cycling in two Cape ecosystems: evidence from soil incubation studies and ${ }^{15} \mathrm{~N}$ natural abundance values. Oecologia, 101, 375-382.

Thomas, R.B., Richter, D.D., Ye, H., Heine, P.R. \& Strain, B.R. (1991) Nitrogen dynamics and growth of seedlings of an $\mathrm{N}$-fixing tree (Gliricidia sepium (Jacq.) Walp.) exposed to elevated atmospheric carbon dioxide. Oecologia, 88, 415421.

Thrall, P.H., Burdon, J.J. \& Woods, M.J. (2000) Variation in the effectiveness of symbiotic associations between native rhizobia and temperate Australian legumes: interactions within and between genera. Journal of Applied Ecology, 37, 52-65.

Thrall, P.H., Slattery, J.F., Broadhurst, L.M. \& Bickford, S. (2007) Geographic patterns of symbiont abundance and adaptation in native Australian Acacia-rhizobia interactions. Journal of Ecology, 95, 1110-1122.

Thuiller, W., Richardson, D.M., Rouget, M., Procheş, S. \& Wilson, J.R. (2006) Interactions between environment, species traits, and human uses describe patterns of plant invasions. Ecology, 87, 1755-1769.

Thuiller, W., Richardson, D.M. \& Midgley, G.F. (2007) Will climate change promote alien plant invasions? Biological invasions (ed. by W. Nentwig), pp. 197-211. Springer, Berlin.

Tinker, P.B. \& Nye, P.H. (2000) Solute movement in the rhizosphere. Oxford University Press, New York.

Turner, I.M. (1994a) A quantitative analysis of leaf form in woody plants from the world's major broad-leaved forest types. Journal of Biogeography, 21, 413-419.

Turner, I.M. (1994b) Sclerophylly: primarily protective? Functional Ecology, 8, 669-675.

Turner, D.P., Cohen, W.B., Kennedy, R.E., Fassnacht, K.S. \& Briggs, J.M. (1999) Relationships between leaf area index and 
Landsat TM spectral vegetation indices across three temperate zone sites. Remote Sensing of Environment, 70, 52-68.

Ullmann, I. (1989) Stomatal conductance and transpiration of Acacia under field conditions: similarities and differences between leaves and phyllodes. Structure and Function of Trees, 3, 45-56.

Vilà, M., Corbin, J.D., Dukes, J.S., Pino, J. \& Smith, S.D. (2007) Linking plant invasions to global environmental change. Terrestrial ecosystems in a changing world (ed. by J.G. Canadell, D. Pataki and L. Pitelka), pp. 93-102. Springer, Berlin.

Vitousek, P.M. (1986) Biological invasion and ecosystem properties: can species make a difference? Ecology of biological invasions of North America and Hawaii (ed. by H.G. Baker, H.A. Mooney and J.A. Drake), pp. 163-178. Springer, Berlin.

Vogel, C.S. \& Curtis, P.S. (1995) Leaf gas exchange and nitrogen dynamics of $\mathrm{N}_{2}$-fixing, field-grown Alnus glutinosa under elevated atmospheric $\mathrm{CO}_{2}$. Global Change Biology, 1, 55-61.

Walters, G.A. \& Bartholomew, D.P. (1984) Acacia koa leaves and phyllodes: gas exchange, morphological, anatomical, and biochemical characteristics. Botanical Gazette, 145, 351-357.

Werner, C., Peperkorn, R., Máguas, C. \& Beyschlag, W. (2008) Competitive balance between the alien invasive Acacia longifolia and native Mediterranean species. Plant Invasions: human perception, ecological impacts and management (ed. by B. Tokarska-Guzik, J.H. Brock, G. Brundu, L. Child, C.C. Daehler and P. Pyšek), pp. 261-275. Backhuys Publishers, Leiden.

Werner, C., Zumkier, U., Beyschlag, W. \& Máguas, C. (2010) High competitiveness of a resource demanding invasive acacia under low resource supply. Plant Ecology, 206, 83-96. van Wilgen, B.W. \& Richardson, D.M. (1985) The effects of alien shrub invasion on vegetation structure and fire behaviour in South African fynbos shrublands: a simulation study. Journal of Applied Ecology, 22, 955-966.

van Wilgen, B.W., Reyers, B., Le Maitre, D.C., Richardson, D.M. \& Schonegevel, L. (2008) A biome-scale assessment of the impact of invasive alien plants on ecosystem services in South Africa. Journal of Environmental Management, 89, 336-349.

van Wilgen, B.W., Dyer, C., Hoffmann, J.H., Ivey, P., Le Maitre, D.C., Moore, J.L., Richardson, D.M., Rouget, M., Wannenburgh, A. \& Wilson, J.R.U. (2011) National-scale strategic approaches for managing introduced plants: insights from Australian acacias in South Africa. Diversity and Distributions, 17, 1060-1075.

Williamson, M. (1996) Biological invasions. Chapman \& Hall, London.

Wilson, J.R.U., Richardson, D.M., Rouget, M., Procheş, Ş., Amis, M.A., Henderson, L. \& Thuiller, W. (2007) Residence time and potential range: crucial considerations in modelling plant invasions. Diversity and Distributions, 13, 11-22.

Witkowski, E.T.F. (1991a) Effects of invasive alien acacias on nutrient cycling in the coastal lowlands of the Cape Fynbos. Journal of Applied Ecology, 28, 1-15.

Witkowski, E.T.F. (1991b) Growth and competition between seedlings of Protea repens (L.) L. and the alien invasive, Acacia saligna (Labill.) Wendl. in relation to nutrient availability. Functional Ecology, 5, 101-110.

Wright, I.J., Westoby, M. \& Reich, P.B. (2002) Convergence towards higher leaf mass per area in dry and nutrient-poor habitats has different consequences for leaf life span. Journal of Ecology, 90, 534-543.

Yelenik, S.G., Stock, W.D. \& Richardson, D.M. (2004) Ecosystem level impacts of invasive Acacia saligna in the South African fynbos. Restoration Ecology, 12, 44-51.

Yelenik, S.G., Stock, W.D. \& Richardson, D.M. (2007) Functional group identity does not predict invader impacts: differential effects of nitrogen-fixing exotic plants on ecosystem function. Biological Invasions, 9, 117-125.

Young, A. \& Young, R. (2001) Soils in the Australian landscape. Oxford University Press, Melbourne.

\section{BIOSKETCH}

Authors' research interests in ecophysiology, biogeochemistry and ecosystem ecology are combined in the shared interest of the ecology of invasive species and their influence on natural ecosystems. Taryn Morris is a doctoral candidate at the University of Colorado, Boulder, and is interested in the environmental controls and ecology of alien plant invasions and how these may change with rapid global change.

Author contributions: T.L.M., M.D.C., K.J.E. and N.N.B. conceptualized the paper, the writing of which was led by T.L.M.

Editor: David Richardson 